Психолого-педагогічні проблеми становлення сучасного фахівця Випуск 2018

УДК 811.111:159.955=111+159.955

DOI 10.26697/9786177089017.2018.283

Ірійчук Катерина Анатоліївна

(C) Ірійчук К. А., 2018

Національний педагогічний університет імені М. П. Драгоманова

\title{
МЕТАФОРА ЯК ВІДОБРАЖЕННЯ НАЦІОНАЛЬНОГО ОБРАЗНОГО МИСЛЕННЯ АНГЛІЙЦІВ
}

У статті з'ясовуються витоки поняття «метафора» та його значення з точки зору вітчизняних та зарубіжних дослідників. Виокремлено поняття «ментальність», «менталітет» та їх значення. Визначено основні характерні особливості англійців. Проводиться аналіз англійських метафор, завдяки яким надається характеристика британській ментальності, яка знаходить відображення в мові, а географічне положення країни виливає на характер та поведінку людей. Досліджено етнічні особливості британців.

Ключові слова: метафора, образне національне мислення, ментальність, менталітет, етнічні особливості британців.

Проблема, їі зв'язок із важливими науковими чи практичними завданнями. В сучасній мовознавчій науці досить широко використовується тенденція щодо використання метафори у різних напрямках: психолінгвістиці, соціолінгвістиці, структурній лінгвістиці, когнітивному мовознавстві, семіотиці та стилістиці.

Мова $є$ основною формою фіксацій наших знань про світ, так само як і джерелом вивчення цих знань, визнаний тісний зв'язок між семантикою слова та когнітивними процесами сприйняття, що обумовлено закріпленням у слові, яке слугує сигналом відображених у мисленні елементів об'єктивного світу, результатів пізнавальної i продуктивної діяльності людини. Оскільки мова - це засіб подання знань, то можна поставити питання про роль метафори в процесі формування, подання та систематизації результатів діяльності людини.

Аналіз публікацій (виділення невирішених проблем). Вчені України та зарубіжжя присвятили свої праці мовній метафорі: Н. Арутюнова, В. Григор'єва, В. Гака, Н. Черкесова, I. Арнольд, Г. Скляревська, І. Толочина, В. Борисова. Мовна метафора добре відображена у працях С. Кураша, Н. Арутюнової, В. Григор'єва, I. Арнольда, Г. Скляревської, Дж. Лакофа, М. Джонсона та інших. Більш детально теоретичні підходи до розуміння метафори були зроблені Г. Гадамером, С. Аверинцевою, Е. Добренком, O. Староселецем (інтерпретаційна модель). Науковці І. Дубровіна, Д. Девідсон, Р. Розов, Л. Альберті дослідили лінгвоаксіологічну 
інтерпретацію метафори, Ю. Караулов, Ж. Ладміраль, В. Костомаров зробили вклад в інтерпретацію метафор в лінгводидактиці і теорії перекладу, М. Мінська, Г. Попова, Дж. Бруннер, Дж. Лакофф провели дослідження з когнітивної метафори.

Аналізуючи метафори, які використовуються в англійській мові, можна стверджувати, що ментальність людей знаходить відображення у мові, а географічне положення країни впливає на характер i поведінку людей.

Говорячи про британців, можна відмітити їх любов до компромісів, що пояснюється географічним положенням острівної країни. Безспірним $є$ той факт, що територія Великобританія та іiі клімат не знають крайнощів. У Великобританії є гори, але вони не високі, є рівнини, але вони змінюються пагорбами. На території держави немає діючих вулканів, але трапляються невеликі землетруси. Звідси, етнічні особливості британців: відсутність крайнощів (too much water drowned the miller - хорошого - потрошку, to pour oil on troubled waters - to calm down a situation - заспокоювати, остуджувати страсті).

Ціль статті - дослідити за допомогою метафор, які використовуються в англійській мові, історію народу, його ментальність та відображення національного образного мислення англійців.

Виклад основного матеріалу, обгрунтування результатів дослідження. Термін «метафора» походить від грецького слова -

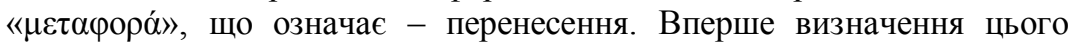
терміну зустрічається в «Поетиці Арістотеля» в розділі «Про мистецтво поезії» [1], згідно з яким «метафора - це перенесення слова iз зміненим значенням 3 роду на вид, або з виду на вид, або за аналогією». 3 даного визначення витікає, що метафора виникає на основі перенесення властивостей, тому ii можна назвати скороченим порівнянням: відбувається заміщення того, що мовець має на увазі, іншим висловом. На нашу думку, дуже важливо підкреслити, що метафора - це саме «перенесення... за аналогією», тобто за схожістю або подібністю, за асоціацією тощо.

У дослідженнях французького літератора Фердинанд де Соссюр знаходимо інформацію про те, що 3 часом вивчення метафори перейшло до стилістики, а саме до образного мовлення, коли метафора почала виконувати образну функцію. Метафору слід розглядати як мовленнєвий, індивідуально реалізований прийом мовця або письменника, який він застосовує, дотримуючись певної фігури та використовуючи певні мовні засоби, оскільки метафора функціонує саме в мовленні. Твердження, що мовлення $\epsilon$ індивідуальним, підтверджується дослідженнями мови та мовлення відомого французького мовознавця Фердинанда де Соссюра і не менш відомого 
німецького вченого Вільгельма Гумбольдта. Саме ці науковці надали більш чіткішого розрізнення та визначення цих двох понять, за яким мовлення включає - індивідуальні комбінації, залежні від мови мовців та - акти фонації - реалізації акустичних образів, які так само залежні від волі мовців і необхідні для здійснення цих комбінацій [5].

Ш. Баллі продовжив вивчення мови та мовлення i зробив особливий внесок у виникнення і розвиток образного мовлення. Автор визначає метафору, як не що інше, як порівняння, в якому розум під впливом тенденції зближувати абстрактне поняття i конкретний предмет поєднує їх в одному слові. Тобто, кожного разу, коли вдається визначити походження образу, людина стикається 3 обмеженістю людського розуму або з однією 3 необхідностей, якій підкоряється мовленнєва діяльність людини. Найбільша недосконалість людського розуму полягає в тому, що він нездібний до абсолютної абстракції; він не може виділити чисте поняття, сприйняти ідею поза будь-яким зв'язком 3 конкретною дійсністю. Людина уподібнює абстрактні поняття предметам чуттєвого світу, бо для неї це єдиний спосіб пізнати їх і ознайомити 3 ними інших. Подібні зближення зазвичай грунтуються на нечітких аналогіях, які іноді є абсолютно нелогічними; проте вони досить зрозуміло показують, що ж саме у зовнішньому світі привертає увагу людини і в яких образах малюється йому те, що його розум не може осягнути в суто абстрактній формі [7].

Поступово 3 вивченням метафори у риториці, лінгвістиці та стилістиці, ii дослідження поширилось в ті галузі знань, які займаються проблемами мислення, пізнання, свідомості та концептуальних систем. На сьогоднішній день прослідковується тенденція до розширеного поняття - метафора. Цим терміном називають не тільки будь-який спосіб образного вираження змісту, який існує в художньому тексті, а й в образотворчому мистецтві: кінематографі, театрі та живописі. Зараз метафора - це не лише стилістичний прийом, але й символ у мистецтві, яка може бути невербальною.

Завдяки такому визначенню метафори можна стверджувати, що метафора - результат процесу образного мислення мовця, яке поєднує різні поняття за аналогією та асоціацією в одному мовленнєвому акті.

У всі часи філософські романтичні погляди сходилися на тому, що метафора є єдиним способом вираження думки, визначення об'єктів високого ступеня абстракції та, навіть, мислення взагалі. Вони стверджували, що пізнання є метафоричним, а й метафора - невід'ємна складова мислення, мовлення та мови. Один із відомих науковців Хосе Ортега-і-Гассет давав наступне визначення метафорі: «Від наших уявлень про свідомість залежить наша концепція світу, а вона, в свою чергу, визначає нашу мораль, нашу політику, наше мистецтво. 


\section{Збірник наукових статей}

Виходить, що вся величезна споруда Всесвіту, сповнена життя, лежить на крихітному та легкому тільці метафори» [3].

Метафора використовується дуже широко в творах англійських авторів. Вона дозволяє створювати різноманіття образів, потрібних для опису героїв, їх почуттів і емоцій, природи, її краси і унікальності і т.д.

Англійський науковець Дональд Девідсон визначає метафору як мовну фігуру, яка безпосередньо стосується однієї речі, згадуючи іншу для риторичного ефекту. Це може забезпечити ясність або визначити прихованість схожості двох ідей. Антитеза, гіпербола, метонімія та подібність - це види метафори [8].

I. Річардс у своїй праці «Філософська риторика» (1973р.) зазначає, що метафора складається із двох частин: тенора (tenor) i засобу переміщення (vehicle). Тенор $\epsilon$ тим предметом, якому підпорядковується обставина, а засіб переміщення $є$ об'єктом, обставина якої запозичується. Так, наприклад, «the world» is compared to a stage, describing it with the attributes of «the stage»; «the world» is the tenor, and «a stage» is the vehicle; «men and women» is the secondary tenor, and «players» is the secondary vehicle. Отже, при перекладі прослідковуємо «світ» прирівнюється до сцени, описуючи його із словом «сцена»; тобто «світ» $є$ тенором, а «сцена»- засобом; «чоловік і жінка» $\epsilon$ другорядним тенором, а «виконуючі ролі» - другорядним засобом [9].

Науковці Дж. Лакофф і М. Джонсон у своїх працях особливу увагу зосереджують на ключових метафорах. Саме завдяки ключовим метафорам проводяться аналогії та вибудовуються асоціації між різними системами понять. Раніше ключовими метафорами займалися переважно культурологи, які вивчали національні картини світу, тепер їх розглядають спеціалісти з психології мислення та методології науки. Вищеназвані автори стверджували, що метафора застосовується не лише в мовленні, але й самі процеси мислення людини значною мірою $\epsilon$ метафоричними» $\mathrm{i}$ - понятійна система людини упорядковується та визначається метафорично. Метафори як мовні вирази стають можливі саме тому, що існують метафори в поняттєвій системі людини. Отже, iз часом з'явилося поняття «концептуальна метафора» [4].

Дж. Лакофф і М. Джонсон розглядають метафору зсередини та зовні. Метафори зсередини функціонують як когнітивні процеси, завдяки яким ми поглиблюємо наші уявлення про світ та створюємо нові гіпотези, а зовні - як - посередники між людським розумом та культурою [4].

Таким чином, метафори не лише змінюють мову, а й світосприйняття. Такий погляд ще раз підтверджує нашу думку, що метафора може розглядатись у вузькому та широкому значенні. У вузькому значенні метафора функціонує у мовленні, а в широкому 
Психолого-педагогічні проблеми становлення сучасного фахівця Випуск 2018

вона функціонує у мові та мисленні (лексичне значення грунтується на понятті), впливає на процеси пізнання, на розвиток мови та, навіть, культури.

На основі вивченої та дослідженої наукової літератури виявлено, що національне образне мислення ототожнюється із термінами «ментальність» та «менталітет».

Визначено, що слово «менталітет» походить від латинського кореня «mens» - свідомість. Часто підкреслюється, що поняття менталітет і ментальність синонімічні i, отже, взаємозамінні. На цій підставі вони розглядаються в одному ряді зі словосполученнями «національний характер», «дух народу», «етнічна психіка», оскільки не мають суттєвих відмінностей у значенні та $є$ перекладом 3 різних європейських мов. Так, різниця між «менталітетом» і «ментальністю» полягає в тому, що ментальність включає в себе типове для певного мовного колективу своєрідне сприйняття світу і специфічний прояв національного характеру. Менталітет включає в себе стереотипне сприйняття навколишньої дійсності, продиктоване етнокультурною свідомістю. Ментальність - складова частина менталітету, перший ступінь його формування [2].

Досліджено, що історичні події, які відбувалися на території Великобританії, значно вплинули на формування народу, його ментальність та на образне національне мислення британського народу.

Власне англійці, а саме так узагальнено називають народи, які проживають на території Великобританії та Північної Ірландії, $\epsilon$ продуктом змішання багатьох етнічних груп - найдавнішого іберійського населення 3 народами індоєвропейського походження: племен кельтів, германських племен англів, саксів, фризів, ютів, в деякій мірі скандинавів, а згодом і франко-норманів [6].

Історики, етнографи та літературознавці наділяють англійців такими рисами характеру як: консерватизм, гордість, трепетне ставлення до свого дому і домашнім тваринам.

Саме від селянської натури англійський характер успадкував схильність до всього природного, простого, нехитрого на противагу всьому штучному, показному, вигадливому: прозаїчну діловитість, яка ставить матеріальний бік життя вище духовних цінностей; відданість традиціям при недовірі до всього незвичайного, тим більше іноземної; пристрасть до домашнього вогнища як символу особистої незалежності. Скандинавські вікінги (професійні мореплавці) внесли в англійський характер ще одну суттєву рису - пристрасть до пригод. В душі господарського англійця завжди відчувається вабливий поклик моря, романтична тяга до далеких берегів [2]. 


\section{Збірник наукових статей}

Отже, в англійському характері втілилися англосаксонська практичність 3 кельтською мрійливістю, піратська хоробрість вікінгів 3 дисципліною норманів.

Аналіз англійських метафор та фразеологізмів дає підстави зрозуміти i визначити британську ментальність, яка знаходить відображення в мові, а географічне положення країни впливає на характер і поведінку людей.

Таким чином, в Великобританії більше, ніж в будь-якій іншій європейській країні, збереглася прихильність до сталих здавна традицій, побуту, звичок, а любов до компромісів, можна припустити, пояснюється географічним положенням острівної держави. Оскільки територія Великої Британії та іiі клімат не знають крайнощів, ми знаходимо мовне підтвердження вищесказаного у фразеології, до складу яких входять природні явища (у Великобританії є гори, але вони не дуже високі, є рівнини, але вони змінюються пагорбами. У Великобританії немає дуже великих річок, взимку не дуже холодно, а влітку не дуже жарко. На території держави немає діючих вулканів, проте трапляються невеликі землетруси).

Визначено етнічні особливості британців:

1) відсутність крайнощів (too much water drowned the millerгарненького потроху);

2) небажання загострювати конфлікти (to water down something - to reduce the severe impact to something (пом'якшувати);

3) to pour oil on troubled waters - to calm down a situation заспокоювати, остуджувати пристрасті;

4) не шкодувати про згаяний, філософський підхід до того, що не може бути змінено (water under the bridge, especially something unfortunate, that cannot be undone or rectified - про невдалу подію в минулому, яка не може бути скасованою або виправленою: що було, те загуло);

5) помірність у всьому (Ebb and flow - злети і падіння). Ключові фрази: Do not rock the boat - не розхитувати човен; Do not go over board - не лізь геть зі шкіри; Do not over do it - не перестарайтеся; All very well in moderation - все добре в міру; Safe and sound - живий i неушкоджений; Order! Order! - Дотримуйтесь порядку!; Happy medium - золота середина;

6) схильність до песимізму (Dead in the water - в глухому куті; In deep water - в біді, в скрутному становищі; Cloud over затьмарювати). Ключові фрази: Huh! Туріcal! - Ха! Ось так завжди!; The countrys going to the dogs - Країна руйнується; What did you expect? - А чого ще ви очікували?; I could have told you - Це відразу було ясно; Better make the best to fit - Чи не падай духом; Never mind - Чи не бери в голову; Blessed are they who expect nothing, for they shall not be 
Психолого-педагогічні проблеми становлення сучасного фахівця Випуск 2018

disappointed - Благословенні ті, хто нічого не чекає, бо вони не будуть розчаровані;

7) справедливість. Ключові фрази: Well, to be fair - Ну, якщо чесно ...; Fair enough Згоден, справедливо; Wait your turn - Жди своєї черги;

8) скромність. Ключові фрази: Do not boast - Чи не хвалися; Stop showing off - Чи не рисуйся; Do not blow your own trumpet - He займайся саморекламою; Do not be clever - Чи не мудрувати; Do not be pushy - Не будь настирливим; I do a bit of sport - Я трохи займаюся спортом (тобто I've just won an Olympic medal - Я тільки що завоював олімпійську золоту медаль);

9) почуття соціальної незручності, яке полягає в тому, що людина відчуває дискомфорт і некомпетентність у сфері соціальної взаємодії (в англійській культурі $є$ таке поняття) (То be a fish out of water (відчувати труднощі, опинившись у незнайомій обстановці), Dead in the water - completely unlikely to succeed (в глухому куті);

10) збентеження, замкнутість, сором'язливість і взагалі не здатність нормально, відкрито спілкуватися з іншими людьми. Мовні приклади: Oh, Comeoffit! - Ой, та буде тобi!; Typical! - Ось так завжди!);

11) гумор, про який окремо необхідно сказати. Гумор для англійців як повітря, без нього вони не здатні функціонувати. Англійський гумор - це рефлекс, мимовільна реакція, особливо коли англійці відчувають дискомфорт або незручність. Not bad - непогано (значить, brilliant - приголомшливо, чудово); A bit of a nuisance прикра неприємність (disastrous, traumatic, horrible - щось жахливе, катастрофічне); Not very friendly - не дуже дружній вчинок (Abominably cruel - акт брудної жорстокості); I may be sometime - Бог дасть, поживу ще (I'm going to die - скоро помру - хоча, звичайно, смішного в цьому мало) [6].

Висновки. Метафора є одним з найбільш продуктивних засобів, завдяки яким відбувається вербалізація дійсності. Вона також $є$ універсальним способом пізнання і концептуалізації дійсного світу, а також є одним із найбільш виразних експресивних мовних засобів, що відрізняються високою інформативністю і семантичною ємністю. Метафорі притаманний також компонент мови, від правильності вибору якого багато в чому буде залежати ефективність комунікації. Метафора є одним 3 найбільш виразних експресивних мовних засобів, що відрізняються високою інформативністю і семантичної ємністю. Крім цього, метафора - це компонент мови, від правильності вибору якого багато в чому буде залежати ефективність комунікації.

Аналіз англійських метафор та фразеологізмів дає підстави зрозуміти i визначити британську ментальність, яка знаходить 
відображення в мові, а географічне положення значною мірою впливає на формування характеру та поведінки.

Визначено, що в англійців збереглася прихильність до сталих здавна традицій, побуту, звичок, а любов до компромісів можна припустити, пояснюється географічним положенням острівної держави. Оскільки територія Великої Британії та ії клімат не знають крайнощів, ми знаходимо мовне підтвердження вищесказаного у фразеології, до складу яких входять природні явища.

Виокремлено характерні особливості англійців, про які дізнаємося при аналізі метафор: відсутність крайнощів, небажання загострювати конфлікти, не шкодувати про згаяне, філософський підхід до того, що не може бути змінено, помірність у всьому, схильність до песимізму, справедливість, скромність, почуття соціальної незручності, яке полягає в тому, що людина відчуває дискомфорт і некомпетентність у сфері соціальної взаємодії (в англійській культурі $є$ таке поняття, збентеження, замкнутість, сором'язливість і взагалі не здатність нормально, відкрито спілкуватися з іншими людьми, гумор, про який окремо необхідно сказати).

\section{Література}

1. Аристотель. Этика. Политика. Риторика. Поэтика. Категории / Аристотель. - Минск : Литература, 1998.

2. Історія європейської ментальності / за ред. П. Дінцельбахера. - Львів : Літопис, 2004. - 720 с.

3. Ортега-и-Гассет Х. Две великие метафоры / Х. Ортега-иГассет; общ. ред. Н. Д. Арутюновой, М. А. Журинской. - М. : Прогресс, 1990.

4. Лакофф Дж. Метафоры, которыми мы живем / Дж. Лакофф, М. Джонсон; общ. ред. Н. Д. Арутюновой, М. А. Журинской. - М. : Прогресс, 1990.

5. Сосюр де Фердинан. Курс загальної лінгвістики / Сосюр де Фердинан; пер. $з$ фр. А. Корнійчук, К. Тищенко. - К. : Основа, 1998.

6. Abels R. The Council of Whitby: A Study in Early Anglo-Saxon Politics / R. Abels // Journal of British Studies. - 1983. - No 23 (1). - P. 125. doi: $10.1086 / 385808$

7. Bally Ch. Lelangagefiguré / Ch. Bally // Traité desty listique française. - 1909. - P. 184-202.

8. Davidson D. What Metaphors Mean. Reprinted in Inquiries Into Truth and Interpretation / D. Davidson. - Oxford, Oxford University Press, 2012. - P. 111-115.

9. Fox K. Watching the English: the hidden rules of English behavior / K. Fox. - London, 2011. - P. 18-24. 
10. Richards I. A. The Philosophy of Rhetoric / I. A. Richards. Oxford: Oxford University Press, 2009. - P. 9-10.

Екатерина Ирийчук. Метафора как отражение национального образного мышления англичан.

В статье выясняются истоки понятия «метафора» и его значение $c$ точки зрения отечественных и зарубежных исследователей. Выделены понятие «ментальность», «менталитет» и их значение. Определены основные характерные особенности англичан. Проводится анализ английских метафор, благодаря которым дается характеристика британской ментальности, которая находит отражение в языке, а географическое положение страны влияет на характер и поведение людей. Исследованы этнические особенности британцев.

Ключевые слова: метафора, образное начиональное мышление, ментальность, менталитет, этнические особенности британцев.

Kateryna Iriichuk. Metaphor as a reflection of the national figurative thinking of the English.

The article explains the origins of the concept of «metaphor» and its significance from the point of view of domestic and foreign researchers. The concept of «mentality», "mentality» and their meanings are singled out. The main characteristic features of the British are determined. An analysis of the English metaphors, which provides a characteristic of the British mentality, is reflected in the language, and the geographic location of the country affects the character and behavior of people. The ethnic characteristics of the British are investigated.

Keywords: metaphor, imaginative national thinking, mentality, mentality, ethnic characteristics of the British.

Стаття надійшла до редакційної колегії: 10.05.2018

Прийнято до друку 10.05.2018

\section{Інформація про автора:}

Ірійчук Катерина Анатоліївна - Науково-навчальний Інститут неперервної освіти Національного педагогічного університету імені М. П. Драгоманова. 